\title{
EVALUATION OF PUBLIC SECTOR INVESTMENT IN THE FIELD OF METAL FORMING - CASE KOSOVO
}

\author{
Burim Fejzaj ${ }^{1}$ \\ Mileta Janjić ${ }^{2}$
}

DOI: https://doi.org/10.31410/ERAZ.2019.49

\begin{abstract}
Knowing that most of the former Yugoslavia countries are in confinement from the 1991-1999 period, production processes have stagnated a lot. Public sector investments have been oriented in road infrastructure. Knowing that many branches of the former Yugoslavia's companies for metal processing have been in Kosovo as well „Amortizatori”, „Zastava”, „Llamkos” and many others factories. Also, we must take in account the wrong policies of public sector investment. Then such an assessment would at least give an overview of the public sector's investment potential due to the failure of the privatization process.

The purpose of this paper is to present the possibilities of public sector investment in this field of metal forming production. The objective of the paper is to present the possibilities and give an explanation of whether it is worth investing in this sector by the public sector. Evaluation of such investments are made with benefit/cost method. This method is adapted knowing that the in benefit-cost analysis method, a project is considered positive, when the net benefit associated with it exceeds its cost.
\end{abstract}

Keywords: Public sector, metal forming, investment, benefit- cost method.

\section{INTRODUCTION}

$\mathrm{T}$ he Government's investment mission in the public sector is not intended to benefit the government, but the purpose of these investments would be how much the people benefit from these investments. Public sector investment is very important for Balkan countries. Public sector investment policies are almost failing and this is because they are probably directed at the wrong side. Many of the deformed metal processing factories have remained unsettled, or privatizations have failed. There has never been an attempt to revitalize them by the government. Even so, no estimates were made whether these investments would be profitable without wanting to return those in state - owned enterprises or to not require government ownership of the assets. Evaluation of public projects is vital and during these evaluations the use of adequate assessment methods is also very important for these assessments. The Government of Kosovo should take into account the investments in this sector as there would be no benefits in shortterm, but in long-term benefits would not be missing and at the same time in the coming years this would have an impact on budget growth.

\section{THEORETICAL VIEW}

Metal forming technology include field of robotics, welding, drawing, presses die casting, joining, sheet metal forming, presses for applications, automation, hydraulic and pneumatic systems and many other processes. Country efforts to "invest in public sector" can play a key role in raising the returns on public investment, and in ensuring that the scaled-up investment reaps

\footnotetext{
1 University of Prishtina, Faculty of Applied Sciences, Rr. Parku industrial, p.n 40000, Mitrovica

2 Faculty of Mechanical Engineering, Bulevar Džordža Vašingtona bb, 81000 Podgorica, Montenegro
} 
the required economic growth, while maintaining their fiscal and debt survival [1]. Also, public capital investments have a social effect, but it depends very much on their efficiency [2].

In order to shift the reality of economic analyzes and assessments of the public sector, as well as to reduce the effects of political and other interests, an analysis model has been developed that takes the value of the benefit / cost ratio as the main parameter, and this method is known as $\mathrm{B} / \mathrm{C}$ [3]. Benefit / Cost method (B/C) is the basic method of analysis for public sector projects, and developed with a view to objectively shifting the economic aspects of the public sector [3]. Decision takers in governments must choose among different project alternatives which, in varying degrees, contribute to society [4].

The basic goal and the steps of this method are shown in Figure 1.

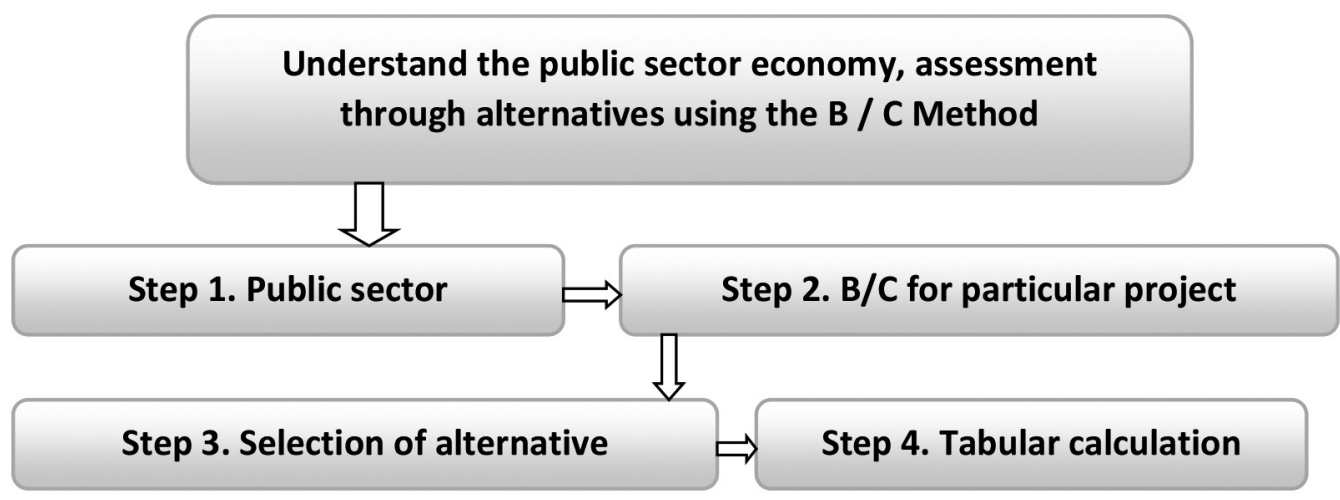

Figure 1. Basic goal of $\mathrm{B} / \mathrm{C}$ method

\subsection{Formulas and calculation}

Historically, public sector projects are funded by the state sector. And those who value these projects should choose between the best alternatives. Below we will present three cases of public sector investment assessment which we will later use for our case.

First the conventional benefit-cost ratio $(\mathrm{B} / \mathrm{C}$ ratio) of the project:

$$
\text { Conventional B } / \text { Cratio }=\frac{P W \text { of benefit }-P W \text { of disbenefit }}{\text { Inital } \cos t+P W \text { of operating } \cos t-P W \text { of salvagevalue }}
$$

Conventional $\mathrm{B} / \mathrm{C}$ ratio using Annual worth:

Conventional B $/$ Cratio $=\frac{A W \text { of benefit }-A W \text { of disbenefit }}{A W \text { of Inital } \cos t+A W \text { of operating } \cos t-A W \text { of salvagevalue }}$

Conventional $\mathrm{B} / \mathrm{C}$ ratio using Future worth:

Conventional $B / C$ ratio $=\frac{F W \text { of benefit }-F W \text { of disbenefit }}{F W \text { of Inital } \cos t+F W \text { of operating } \cos t-F W \text { of salvagevalue }}$

Or in the simplest way:

$B / C=\frac{P W \text { benefit }}{P W \cos t}=\frac{A W \text { benefit }}{A W \cos t}=\frac{F W \text { benefit }}{F W \cos t}$

Performing benefit-cost $(\mathrm{B} / \mathrm{C})$ ratio analysis, of project: 
Table 1. Performing benefit-cost (B/C) adapted from [5]

\begin{tabular}{l|l}
\hline \hline \multicolumn{1}{c|}{ Condition } & \multicolumn{1}{c}{ Appropriate Criterion } \\
\hline \hline $\begin{array}{l}\text { Only one investment alternative is under } \\
\text { consideration }\end{array}$ & $\begin{array}{l}\text { Invest in the alternative if the B/C ratio is greater than or equal to } \\
1.0 \text {. Otherwise do not invest in the alternative. }\end{array}$ \\
\hline $\begin{array}{l}\text { Two or more investment alternatives are } \\
\text { under consideration }\end{array}$ & $\begin{array}{l}\text { Perform incremental B/C analysis. At each step, choose the higher } \\
\text { cost alternative if the incremental B/C ratio is greater than or equal } \\
\text { to } 1.0 \text {. Otherwise choose the lower cost alternative. }\end{array}$ \\
\hline \hline
\end{tabular}

\section{METAL DEFORMATION SECTOR IN KOSOVO}

The metal forming sector in Kosovo suffered a huge devastation and this is due to inadequate public property management policies. Attempts to privatize these factories are failing the cause of privatization without criteria. Of all the factories in 2000 where they were over 50, only Llamkos factory with its headquarters in Vushtrri remained.
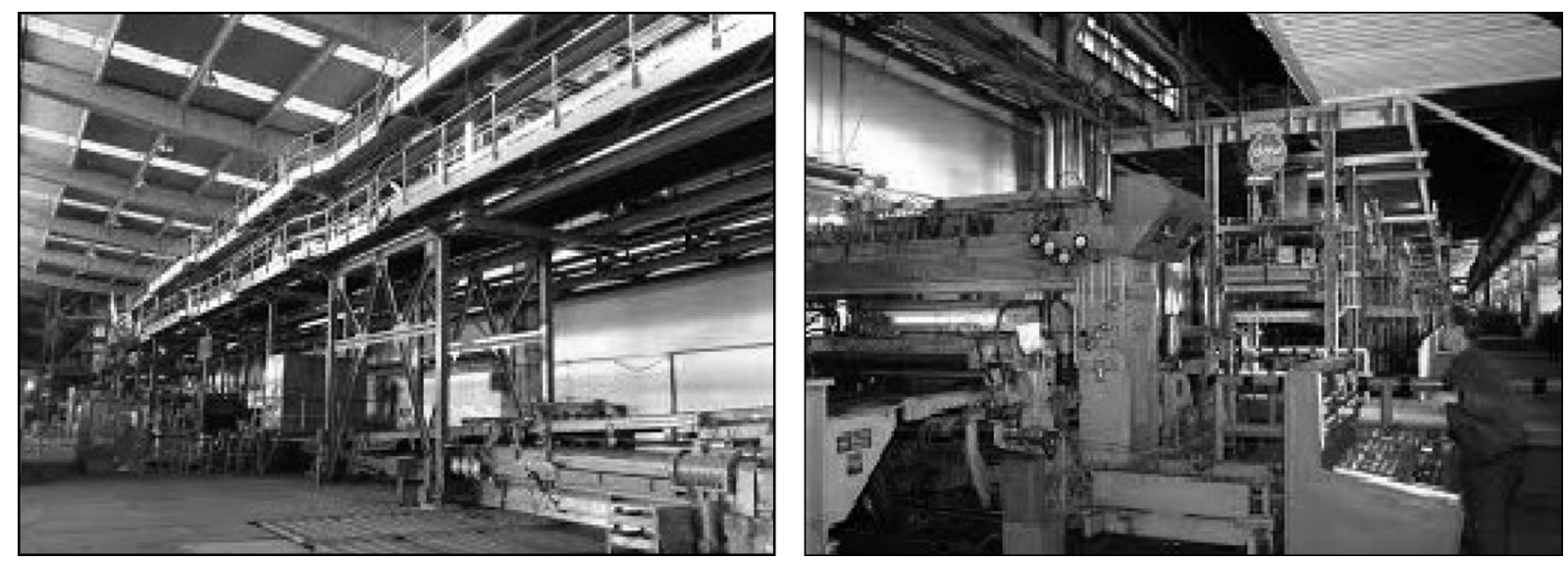

Figure 2. The remaining machinery in 2000 .

Privatization and the failure of revitalization would probably give the government the opportunity to invest even though recently it has been privatized. Take the example of the Zastava factory in Peja, which once employed more than 2000 workers, today after privatization has become a market. The machine that was almost new is not known where it has dissolved, and this is the wrong politics followed by the government. Then the Amortizator factory in Pristina, which once had more than 1000 employees, was sold for 7.5 million euros. Today, after privatization, there has been no investment opportunity from anyone.

\section{B/C METHOD IN EVALUATION OF PUBLIC SECTOR INVESTMENT IN THE FIELD OF METAL FORMING}

The allocation of the budget in these years in Kosovo goes only for infrastructure and nothing else, without any good for the work power. This is affecting the private sector being overwhelmed with workers and this is giving many opportunities for businesses in many misuses. Let's take the case if investments of 350 mil euros of infrastructure are reduced to $150 \mathrm{mil}$, and 200 mil go to the manufacturing sector, especially to the revitalization of these factories.

The Association of metal forming producers receive from government a fund of 200 mil Euro. This money will be distributed for 20 years by 10 mil euro. The Association uses an annual discount rate of 5\% - 7\%. 1.200,000 euro per year will be operational costs which will be provided by regular budget; and $800.000 €$ from other donors. 
Aw investment costs $=200000000(\mathrm{~A} / \mathrm{P}, 5 \%-7 \%, 20)$, Aw annual costs $\mathrm{M} \& \mathrm{O}=1.200 .000 €$

Aw benefits $=10.000 .000 €$, Aw disbenefits $=800.000 €$. After all calculation the $\mathrm{B} / \mathrm{C}$ ratio is 1.0049.

Table 2. Evaluation of public sector investment

\begin{tabular}{|c|c|c|}
\hline Public Sector Discount Rate & $5.00 \%$ & $7.00 \%$ \\
\hline Appraisal period (years) & 20 & \\
\hline Capital Costs & $€ 0$ & $€ 0$ \\
\hline Whole of Life Costs & $200,000,000 €$ & $200,000,000 €$ \\
\hline Present Value of Benefits & $127,699,656 €$ & $109,585,335 €$ \\
\hline Present Value of Costs & $127,699,656 €$ & $109,585,335 €$ \\
\hline Benefit Cost Ratio & 1.00 & 1.00 \\
\hline Net Present Value & $€ 0$ & $€ 0$ \\
\hline
\end{tabular}

\section{CONCLUSION}

Based on Table 1, and comparing the conditions under which an investment in the public sector can be considered acceptable and by looking at the value gained from the project evaluation, we can say that: The investment with the stated amount and the time of return of investments for 20 years would affect long-term profits. Here it is seen that the metal sector needs an investment from government. For the estimated period and the investment for the amount mentioned would bring the country a profit of $127,699,656 €$. The greatest benefit would be the employment of young people. Employing in this sector would have a major impact on increasing the quality of education at faculties due to the demand of professional staff. From calculations with method B / $\mathrm{C}$ as well as adapting the real interest rate in Kosovo varies from (5 to 7), it is seen that we may have a change of profit but with a little higher risk.

\section{REFERENCES}

[1] Collier, P. and Venables, A., 2008, "Managing Resource Revenues: Lessons for Low Income Countries," African Economic Research Consortium 2008 Annual Conference

[2] Pereira, A. \& Andraz, J. (2013) On the Economic Effects of Public Infrastructure Investment: A survey of the International Evidence. Working Paper No.108. College of William and Mary, Department of Economics, July 2013.

[3] Vukcevic M., Inzinjerska ekonomija, Univerzitet Crne Gore -Masinski fakultet, Podgorica 2012

[4] Sijtsma, F.J. / Project evaluation, sustainability and accountability: combining cost-benefit analysis (CBA) and multi-criteria analysis (MCA). s.n., 2006. 302 p.

[5] Shively, Gerald. (2012). An Overview of Benefit-Cost Analysis.

[6] Boardman, A.E., D.H. Greenberg, A.R. Vining and D.L. Weimer (1996). Cost Benefit Analysis: Concepts and Practice. Englewood Cliffs, NJ: Prentice Hall. 